\title{
PAUL GAUGUIN I VICTOR SEGALEN: ESTETYKA ODMIENNOŚCI POMIĘDZY LITERATURA A MALARSTWEM
}

\author{
AleKSANDRA MANČić \\ (Institut za književnost i umetnost, Beograd)
}

\begin{abstract}
Słowa kluczowe: Paul Gauguin, Victor Segalen, sztuka prymitywna, estetyka odmienności, krytyka postkolonialna

Key words: Paul Gauguin, Victor Segalen, Primitivist Artist, Aesthetics of Diversity, Post-colonial Criticism
\end{abstract}

\begin{abstract}
Abstrakt: Aleksandra Mančić. PAUL GAUGUIN i VICTOR SEGALEN: ESTETYKA ODMIENNOŚCI POMIĘDZY LITERATURĄ A MALARSTWEM. „PORÓWNANIA” 19, 2016. T. XIX. S. 41-57. ISSN 1733-165X. Nowoczesna refleksja dotycząca inności wiedzie przez różnorodne kultury (transkulturalnie), sztuki oraz dyscypliny (transdyscyplinarnie) i podejmuje zagadnienia, które w niniejszym artykule ujęte zostały w ramy problematyki podróży i przekładu (translacji), od twórczości malarza Paula Gauguina do dzieł pisarza Victora Segalena i ich artystycznych poszukiwań oraz przemyśleń na temat egzotyzmu i sztuki prymitywnej, będących odpowiedzią na niwelowanie różnic w wyniku praktyk kolonizacyjnych.
\end{abstract}

\begin{abstract}
Aleksandra Mančić. PAUL GAUGUIN AND VICTOR SEGALEN: AESTHETIC OF DIVERSITY BETWEEN WRITING AND PAINTING. "PORÓWNANIA" 19, 2016. Vol. XIX. P. 41-57. ISSN 1733-165X. An example of modern thought on otherness is the one going across different cultures (transcultural) leading across different arts and different disciplines (transdisciplinary), tackling the issue fundamentally posed as an issue of travel as well as of translation (translational): the line that leads from the painter Paul Gauguin to the writer Victor Segalen in their search for new visions and reflections related to Exoticism and Primitivist art is a tentative response to the decline of diversity triggered by colonialism.
\end{abstract}

Relacje z podróży, zapiski badaczy i zdobywców potwierdzają fakt, że fascynacja Innością i Odmiennością nie jest zjawiskiem zaskakującym. Żyjemy w świecie pozornie faworyzującym wszelkie kontakty międzykulturowe, także te zachodzące między przeciwstawianymi sobie kulturami, a Inność oraz Odmienność nadal wzbudzają zainteresowanie turystów, antropologów, etnologów, psychologów, 
filozofów oraz artystów. Dlatego warto poddać badawczej refleksji nasz sposób postrzegania i rozumienia odmienności, która zawsze jest inna i warunkowana perspektywą obserwatora. Przykład europejskiego namysłu nad polinezyjską innością pokazuje, że pomimo zmian, jakim w miarę upływu czasu ulegał sposób jej postrzegania, nadal obecne są w nim pewne miejsca stałe, których geneza sięga jego początków. Ich obecność pozwala dostrzec fakt, że obserwacja innego zawsze w końcu wiedzie obserwatora ku samopoznaniu: inny, będący przedmiotem refleksji, odpowiada obserwującemu, zwracając mu jego pytanie. Poszukiwania tożsamości, samookreślenia uruchamiają proces, który ma charakter zwrotny. Ujęty w takie ramy badawcze przykład nowoczesnej refleksji nad polinezyjską innością w sposób nieunikniony wiedzie drogą wyznaczoną przez różnorodne kultury (transkulturowo), sztuki oraz dyscypliny (transdyscyplinarnie) ku zagadnieniu, które u swoich podstaw jest problemem przekładu (translacji) jako podróży. Ujmując rzecz prościej, możemy przedmiotem rozważań uczynić twórcze poszukiwania i refleksje na temat egzotyzmu pewnego malarza - Paula Gauguina - i pewnego pisarza Victora Segalena, które zawiodły obu artystów do pytania: kto naprawdę jest obserwowanym, a kto obserwującym?

Spotkanie Europejczyka z Polinezyjczykiem stanowi paradygmatyczną sytuację, w której podmiot próbuje zdefiniować siebie za pośrednictwem innego. Poszukiwania tożsamości odmiennej od własnej poprzez procesy alteracji, w których podmiot, nie potrafiąc odnaleźć siebie wewnątrz tego, co go konstytuuje, poszukuje innych form tożsamości w celu odnowienia swojej własnej, są formami jej permanentnego wytwarzania. Jednak przypadek określania własnej tożsamości poprzez dostrzeżenie $\mathrm{w}$ innym różnicy nie stanowi oczywistej alteracji, którą cechuje to, że podmiot w innym dostrzega jedynie to, co jest mu znane, kwestionując różnice dzielące go od innego. Posługując się językiem semiotyki Jurija Łotmana, jest to proces, w którym podmiot przemieszcza się na peryferie swojej wiedzy w poszukiwaniu inności. Centrum semiosfery, jako stabilny ośrodek, jest miejscem kształtowania języków najlepiej rozwiniętych; jest to miejsce języka macierzystego, natomiast peryferie to strefa niestabilności, translacji. Z tego powodu powodzenie przedsięwzięcia podmiotu udającego się na peryferie semiosfery $w$ celu rewitalizacji swojej tożsamości jest nieprzewidywalne. Jest to sytuacja porównywalna z sytuacją podróżującego: podmiot znajduje się w stanie napięcia, oscylując pomiędzy dwiema semiosferami (Lotman 1984).

W tym miejscu fenomen inności wykracza poza sprawozdawczy charakter relacji z podróży i wiedzie ku analizom filozoficznym oraz antropologicznym. Zachodni dyskurs o Polinezji stopniowo zamykał się we własnych uprzedzeniach, przetwarzając kulturę polinezyjską w jednoznaczną inność. Radykalna odmienność cywilizacji polinezyjskiej sprawiła, że od wieków stanowiła ona obiekt fascynacji i intelektualnych wysiłków badawczych opatrywanych najprzeróżniejszymi etykietami. Analiza miejsc wspólnych obecnych w dyskursie o Polinezji wykazuje, że źródłem epistemologicznej niemożności spotkania z innym jest sam podmiot, który 
zamiast postrzegać innego jako obcego, projektuje na innego własne wyobrażenie o nim. Francuski antropolog Bernard Rigo wyjaśnia ten fakt, posługując się teorią "kulturowych ekranów”, czyli przesądów, przez pryzmat których postrzegamy innego. Aby je przezwyciężyć, należałoby przeanalizować sposób, w jaki o inności wypowiadali się podróżnicy, badacze, kolonizatorzy, autorzy relacji z podróży, misjonarze, duchowni oraz bohaterowie niniejszego tekstu, których spotkanie już teraz określić można mianem egzotycznego: artyści - malarz oraz pisarz - poszukujący sposobu ucieczki przed wspomnianą projekcją siebie na innego oraz wyeliminowania krępujących ich epistemologicznych ograniczeń (Rigo 1997, 2004). Analiza stosunku Victora Segalena do Paula Gauguina umożliwia zrozumienie sposobu, w jaki pierwszy z twórców odnajdywał w Polinezji swoją drogę do literatury, sposobu, w jaki kontakt Gauguina ze skrajnie inną kulturą polinezyjską oraz jego radykalnie odmienne spojrzenie na nią odcisnęły swoje piętno na koncepcji egzotyzmu Segalena.

Badania naukowe w rejonie Południowego Pacyfiku zawładnęły wyobraźnią naukowców i artystów pod koniec XVIII wieku. Oświeceniowi filozofowie postrzegali Tahiti jako urzeczywistnioną utopię źródłowej niewinności życia dzikich i wolnych Tahitańczyków. Denis Diderot w 1772 roku zapisał w Supplément au voyage de Bougainville (Suplement do podróży de Bougainville'a): „Życie dzikich jest niezwykle proste, podczas gdy nasze społeczeństwa są tak skomplikowanymi maszyneriami! Mieszkaniec Tahiti dotyka początku świata, zaś Europejczyk - jego starości" (Diderot 173). Voltaire po przeczy taniu zapisków marynarza skonstatował: „Z $Z$ całym przekonaniem można stwierdzić, że mieszkańcy Tahiti wyznają najstarszą religię na ziemi" (Voltaire 702-703). Kolonialna Francja chętnie wykorzystywała idylliczną wizję życia na Tahiti. Podczas Wystawy Światowej w Paryżu, w 1889 roku wyspę reprezentowało około dziesięciu Tahitanek, zbudowano też dwa typowe tahitańskie domy specjalnie na potrzeby wystawy, którą oglądał Paul Gauguin.

Pięćdziesiąt lat wcześniej Markizy odwiedził amerykański pisarz, Herman Melville. Pokłosiem tej podróży była książka o słynącym z ludożerstwa plemieniu Taipi: Typee: A Peep at Polynesian Life (Taipi - spojrzenie na życie Polinezyjczyków, 1846), wśród których kilka miesięcy mieszkał. Melville w powieści opartej na swoich doświadczeniach rozprawiał się z romantycznymi stereotypami na temat mórz Oceanu Południowego, wnikliwie zgłębiając informacje o Polinezji i tworząc kronikęnadużyć, jakich wobec wyspiarzy dopuszczali się handlowcy i misjonarze na Markizach, nie pomijając także działalności amerykańskich misjonarzy na Hawajach.

Szkot Robert Louis Stevenson odwiedził wiele polinezyjskich wysp, od Hawajów do Samoe, notując swoje obserwacje dotyczące wysp koralowych, francuskich 
żandarmów, brytyjskich i amerykańskich władz kolonialnych, kupców, protestanckich i katolickich misjonarzy, wyspiarskich legend i obyczajów. W relacjach z podróży In the South Seas (Z mórz Oceanu Południowego, 1896) na temat geologii, socjologii, prawodawstwa, polityki, etnologii i lingwistyki, dostrzegał paralelizm życia, kultur i języków plemion zamieszkujących wyspy rozsiane na tej rozległej przestrzeni, słowem, podejmował kwestie, które jeszcze sto lat później stanowić będą przedmiot żywej dyskusji naukowców.

Pierre Loti, przebywający krótko na Tahiti, „ziemi snów” w 1872 roku, napisał powieść Rarahu o swoim egzotycznym związku z młodą Tahitanką. Książka opublikowana w 1880 roku wzbudziła zachwyt czytelniczej publiczności i krytyków, stając się bestsellerem, lekturą obowiązkową dla każdego podróżnika, odwiedzającego Polinezję. Czytali ją Paul Gauguin oraz, później, Victor Segalen, a Van Gogh postrzegał jako zaproszenie do podążania śladami malarstwa Gauguina, chociaż on sam raczej dystansował się od tego zbyt - jego zdaniem - popularnego pisarza.

Paul Gauguin był jednym z najbardziej niezwykłych i najbardziej nowatorskich artystów końca XIX i początku XX wieku. Jaskrawe, nienaturalistyczne kolory, jasne kontury postaci na jego obrazach, abstrakcjonizm rzeźb silnie oddziaływały na rozwój sztuki w XX wieku. Wówczas, kiedy twórczość Gauguina umieścimy w kontekście coraz bardziej przyspieszającego tempa życia zglobalizowanego świata, staje się jasne, że transkulturowe poszukiwania francuskiego artysty stały się możliwe dopiero $w$ takim właśnie świecie. Gauguin podzielał panujące w jego czasach poglądy na temat odmienności kulturowej, religijnej i rasowej, ale był też w pewnym sensie dla tych czasów niemałym wyzwaniem. Jego długie podróże oraz decyzja o opuszczeniu Francji i osiedleniu się na wyspach Mórz Południowych, przyczyniły się do powstania legendy Gauguina - ostatniego artysty-cygana i europejskiego poszukiwacza przygód. Paul Gauguin przez długi czas, i słusznie, był uznawany za bohatera sztuki nowoczesnej, malarza, który uwolnił malarstwo od „wierności naturze“" wyzwolił kolor, otworzył wyobraźnię Zachodu na siłę, potęgę i piękno tzw. sztuki prymitywnej (Huyghe 238). W czasach postmodernizmu środki wyrazu stosowane przez Gauguina uznano za nierozerwalnie związane z opowieścią, fabułą i mitem (Thomson 10). Ten często błędnie interpretowany, ale istotny komponent twórczości francuskiego artysty oddziaływał na dwuznaczny stosunek Gauguina do sztuki nowoczesnej, negującej przedstawieniowy narratywizm oraz na akceptację i odrzucenie przez artystę symbolizmu końca XIX wieku.

W 1888 roku, kiedy współpracował z Vincentem van Goghiem i Émilem Bernardem, Gauguin zaczął oddalać się od impresjonizmu, dramatycznie upraszczając swój styl, w którym pojawiają się jasne i zdecydowane kontury. Gauguin odnajduje nowe stylistyczne źródła - japońskie rysunki, ilustracje książek dla dzieci - które zaczęły wyznaczać kierunek jego artystycznej wyobraźni. Styl, który narodził się w latach wspólnego eksperymentowania, prowadził - przez wystawę w Bruk- 
seli i Światową Wystawę w Paryżu - ku nowym tematom. Obrazy, rzeźby i ceramika z tego okresu (1888-1889), powstałe - po pobycie w Prowansji - w Bretanii, gdzie pracował $\mathrm{w}$ kolonii malarskiej $\mathrm{w}$ Pont-Aven, przedstawiają podania bretońskie i mroczne strony rustykalnej seksualności. W tekstach, szczególnie zaś w listach, które wówczas pisał, pojawia się problematyka sztuki wykraczającej poza to, co widzialne, poszukującej poetyckich znaczeń zagubionych w wielkim zwrocie ku naturalizmowi. W impresjonizmie Gauguin widzi kierunek odznaczający się brakiem intelektualizmu, sprowadzający się do wrażeń wzrokowych, podczas gdy on sam oddaje się poszukiwaniom tego, co niewidzialne, nieznane, tego, co - jak twierdził - osiągnął w La Vision après le sermon ou La Lutte de Jacob avec l'ange (Wizja po kazaniu, 1888), płótnie, które stało się jednym z bardzo ważnych obrazów malarstwa symbolicznego (Berban 415). Malując w tropikach, oddalony tysiące kilometrów od Paryża, Gauguin podąża ku otwarciu się na to, co irracjonalne, tajemnicze oraz symboliczne, na to, co już od obrazów powstałych w Bretanii, było nieodłączną cechą jego twórczości.

W październiku 1897 roku, rozczarowany słabą sprzedażą swoich obrazów w Paryżu, Gauguin pisał do Monfrieda o swojej wierze w nadejście czasów, kiedy ludzie uwierzą w to, że jest on „mitem czy raczej dziełem prasy” (Joly-Segalen 1950: 113). W 1902 roku przytłaczał go ciężar decyzji o spędzeniu reszty życia w odosobnieniu. Na wyspach Polinezji marzył o tym, by znaleźć się w Pirenejach, obok Daniela de Monfrieda, ale jego wieloletni przyjaciel odwodził Gauguina od tego, pisząc, że powrót oznaczałby jego śmierć, fizyczną śmierć ciała, nadwyrężonego przez choroby, ale także śmierć mitu artysty Gauguina:

Jest Pan teraz nieprzeciętnym artystą - legendą, który z głębin Oceanii wysyła swoje niepokojące, niepowtarzalne dzieła, ostateczne dzieła wielkiego człowieka, który zniknął, że tak powiem, z powierzchni ziemi. [...] Ujmując problem lapidarnie - dziś cieszy się Pan nietykalnością martwego giganta, już teraz należy Pan do historii sztuki (Joly-Segalen 1950: 233-234).

Paul Gauguin przybył na Tahiti w 1891 roku jako dojrzały artysta, autor arcydzieł, artystycznych manifestów, takich jak Wizja po kazaniu (Vision après le sermon 1888) czy Żótty Chrystus (Le Christ jaune, 1889), poruszających tematykę sacrum. Pobyt na Tahiti w znacznym stopniu przeobraził malarza, ale to, co odnalazł na wyspie, udało mu się odkryć znacznie wcześniej. Dotarcie do „ekscentrycznego” miejsca, jakim była na mapie chrześcijańskiej Francji „pogańska” Bretania, stanowiło impuls, który wyzwolił w nim zainteresowanie religią jako przedmiotem artystycznej i filozoficznej refleksji, będącej odtąd stałym motywem jego twórczości malarskiej, ale i literackiej. Jednak najbardziej fascynującym tematem prac Gauguina był on sam, co uwidacznia się w liczbie namalowanych przez niego autoportretów oraz 
np. w fakcie użyczania swojej twarzy postaci sportretowanego Chrystusa (Chrystus w ogrodzie oliwnym; Le Christ dans le jardin des oliviers, 1889) oraz innym osobom pojawiającym się na jego zróżnicowanych tematycznie płótnach. Gauguin to artysta kreujący swój własny mit za pomocą autoportretów, w których dokonuje on projekcji różnorodnych wyobrażeń o sobie. Przedstawiciel kultury pierwotnej, dzikus, przedstawiciel świata cywilizacji usiłujący uwolnić się od niej, święty, grzesznik, Chrystus i diabeł to postaci, za pomocą których przedstawia siebie na obrazach i w tekstach, bawiąc się przydzielonymi sobie rolami i dystansując się do nich.

Gauguin nie realizował się wyłącznie jako malarz, oprócz malarstwa i grafiki uprawiał także rzeźbę, tworzył teksty literackie, studiował etnologię i wiedzę o religiach. Wszystko to zaś stanowiło realizację jego podróżniczej pasji, której punktem dojścia był obraz, najważniejszy, choć nie jedyny środek przekazu Gauguina. Podczas pobytu na Tahiti bowiem, zawładnęła nim pewna nowa, potężna energia. Była to energia ludzkiego ciała...

Poeta i wizjoner Victor Segalen jest czołowym twórcą XX-wiecznego podróżopisarstwa francuskiego. Kluczowe dzieło Segalena to esej o egzotyzmie, w którym "odmienność" i „boskość” zostają ze sobą bardzo ściśle połączone. Jako pierwsze czytelniczą uwagę zwróciły poezja, eseistyka oraz powieści będące pokłosiem jego podróży po Chinach. Wywodzący się z Bretanii Segalen za jednego ze swoich pierwszych literackich mistrzów uznał Julesa de Gaulthiera, który w książce Le Bovarysme (Bowaryzm) badał paradoksy inności. Artykułem: Les Synesthésies et l'école symboliste (Synestezje i szkoły symbolistyczne, 1902) Segalen zwrócił na siebie uwagę niezwykle wówczas wpływowego Rémy de Gourmonta, który wprowadził go w środowisko związane z czasopismem „Mercure de France”. To tutaj Segalen poznał André Gide'a, Bretończyka Saint-Pol-Rouxa oraz kompozytora Claude'a Debussy'ego, dla którego napisał trzy libretta operowe.

W celach zarobkowych Segalen podjął pracę lekarza we francuskiej piechocie morskiej. Profesja ta zawiodła go w 1902 roku na Tahiti. Pobyt na wyspie i kontakt z dziełami Gauguina zaowocowały zalążkami eseju o egzotyzmie i powieścią Les Immémoriaux (Niezapamiętany świat, 1907), przywołującą obraz życia Polinezyjczyków w czasach pierwszych misjonarzy. Podobnie jak Gauguin, Segalen nie starał się przedstawić współczesności, lecz rekonstruował zmierzch pewnej cywilizacji, i podobnie jak Gauguin, pragnął, by stała się ona wyzwaniem dla cywilizacji europejskiej. Segalen zdołał ukończyć swoją powieść, ale aż do samej śmierci w 1919 roku pracował nad tekstem Essai sur l'exotisme: Esthetique du Divers (Esej o egzotyzmie: estetyka odmienności), swoim najważniejszym, nieukończonym dziełem, opublikowanym w dwóch częściach w czasopiśmie "Mercure de France” dopiero 
w 1955 roku, po odkryciu jego rękopisu przez poetę Pierre'a Jeana Jouve'a. Przeznaczenie tych notatek nie jest znane, ale po ich wydaniu odczytano je jako swoisty manifest, dostrzeżony przez antropologa - Claude'a Levi-Straussa oraz pisarzy i etnografów - Michela Leirisa czy Henriego Michaux. Pytania dręczące Segalena wydają się aktualne także dzisiaj: gdzie w świecie, który staje się coraz bardziej ciasny, odnaleźć życie nie skażone naszym?

Segalen dostrzega wszystkie wady terminu "egzotyzm”, jednak z braku lepszego, za jego pomocą oznacza byt (entity), który na zawsze pozostaje wydzielony. Kluczowy jest jednak dla Segalena fakt względności sposobu doświadczania egzotyzmu: to, co egzotyczne dla jednych, nie jest takie dla innych. Badacz odchodzi od rozpatrywania egzotyzmu $\mathrm{w}$ przestrzeni i w czasie, koncentrując się na badaniu różnorodności i wielości form, jakie egzotyzm przyjmuje: „Możliwe - pisze - że jedną z cech egzotyki jest wolność, fakt, że jest ona wolna w odniesieniu do przedmiotu, który opisuje lub który czuje" (Segalen 2014: 60). Segalen łączy egzotyczne $\mathrm{z}$ erotycznym, odmienne (divers) z boskim (divin). Homofonia staje się dla niego impulsem do rozwijania pojęciowych zbieżności. Egzotyzm i erotyzm przywołują problemy rozgraniczania, empatii, posiadania... Granica między mna i tym, co odmienne jest niezauważalna; każde wykroczenie narusza tajemnicę, a wraz z nią i potęgę inności.

Kiedy w styczniu 1903 roku Viktor Segalen przybył na Tahiti, na Markizach pięćdziesięciopięcioletni Paul Gauguin właśnie wdał się w kolejny spór z lokalnymi władzami, zakończony wyrokiem skazującym Gauguina na karę pieniężną. Ponieważ nie był w stanie jej zapłacić, groził mu trzymiesięczny pobyt $\mathrm{w}$ więzieniu. Zamierzał udać się na Tahiti, aby odwołać się od decyzji sądu. W tym czasie Victor Segalen, dwudziestopięcioletni lekarz francuskiej marynarki, członek załogi statku Dirans, stał się autorem opublikowanej niedawno rozprawy L'Observation médicale chez les écrivains naturalistes (Obserwacja medyczna u pisarzy naturalistów), której podstawę stanowiła jego praca doktorska. Krótką i burzliwą karierę pisarską Segalena - po opuszczeniu Tahiti wiele lat spędził na podróżach po Chinach - stymulowały rejsy odbywane $w$ ramach pełnionych przez niego obowiązków lekarza francuskiej marynarki wojennej. Kontakty z radykalnie odmiennymi, ,"egzotycznymi" kulturami sprawiły, że stał się on myślicielem, który w badaniach nad problematyką kontaktów międzykulturowych już na początku XX wieku ściśle łączył ze sobą kwestie odmienności kulturowej oraz problematykę przyczyn wygasania niektórych kultur (Glissant 1990; Todorov).

Przybycie Segalena na Hiva Oa, jedną z wysp należących do archipelagu Markizy, w sierpniu 1903 roku badacze nazywają "niedoszłym spotkaniem wielkiej 
wagi" (Clifford 152). Gauguin zmarł niespodziewanie 8 maja 1903 roku na zawał. Następnego dnia został pochowany na miejscowym cmentarzu katolickim. Okręt Segalena przemierzający $w$ tym czasie wody archipelagu Tuamotu w lipcu powrócił do Tahiti. W sierpniu, gdy miejscowe władze zorganizowały w Papeete aukcję spuścizny po Gauguinie, na jego pokładzie przetransportowano z Hiva Oa do Tahiti wszystkie rzeczy będące własnością francuskiego malarza. W domu miejscowego oficjela Segalen mógł przejrzeć skrzynie z rękopisami i korespondencją Gauguina, a podczas rejsu miał dość czasu, by przepisać z nich wiele fragmentów, które umieścił w swoim Journal des îles (Dziennik z wyspy). Po powrocie do Papeete Segalen uczestniczył w aukcji spuścizny po Gauguinie, która zmieściła się w piętnastu skrzyniach. Licytacja ta, nazwana przez historyków literatury "jedną z kluczowych odsłon egzotyzmu w świecie frankońskim" (Clifford 152) znakomicie obnażała jego względność - we Francji Segalen słyszał prześmiewcze komentarze na temat „szaleńca malującego różowe konie” (Segalen 1995: 349), podczas aukcji na Tahiti ogromnym zainteresowaniem cieszyła się maszyna do szycia, która uzyskała najwyższą cenę. Obraz Bretońska wioska w śniegu (Village breton sous la neige, około 1894) prowadzący licytację nieopatrznie odwrócił i nadał mu tytuł Wodospady Niagara (Joly-Segalen 1944: 78). Zakupił go Segalen. Wszystkie posiadane przez siebie pieniądze - nieco mniej niż wynosiła wówczas jego ówczesna miesięczna pensja - wydał na obrazy i rękopisy Gauguina. Nabył: Scenę z życia na Tahiti (Scène de la vie tahitienne, 1896), Autoportret na Golgocie (Autoportrait près du Golgotha, 1896), Boże Narodzenie (La nuit de Noël, 1898), rzeźbę Idol z muszla (Idole à la coquille, 1893) i obraz Barka (La barque, 1896), z którymi namaluje go przyjaciel Gauguina, później także jego oddany znajomy - Daniel de Monfried.

Podjęta przez Segalena „akcja ratunkowa” była jednocześnie ważnym momentem, który stał się katalizatorem pośmiertnej sławy Gauguina. Segalen zdołał zakupić, a następnie przewieźć do Francji siedem z dziesięciu obrazów wystawionych na sprzedaż, dużą ilość grafik, fotografii, rysunków, książek, notatników i grawiur, łącznie z drewnianymi płaskorzeźbami umieszczonymi przy wejściu do Domu Rozkoszy Gauguina w Atuonie. Wiele lat później zostały one wykupione przez Louvre.

Segalena i Gauguina łączyło bretońskie pochodzenie oraz kontakty z intelektualistami i artystami skupionymi wokół paryskiego czasopisma „Mercure de France". Gdyby doszło do bezpośredniego spotkania twórców, zapewne połączyłyby ich także relacje towarzyskie. Brak takiej formy kontaktu nie stanowił jednak dla Segalena przeszkody, bowiem jego kluczem do twórczości Gauguina stały się dzieła i mit artysty. Podczas kolejnych piętnastu lat, do śmierci, Segalen pracował nad koncepcją estetyki odmienności (Esthetique du Divers), nie ustając w próbach zrozumienia i wyjaśnienia egzotyzmu przez pryzmat przemyśleń związanych ze swoim pierwszym ",spotkaniem" ze spuścizną po Gauguinie.

W latach dziewięćdziesiątych XX wieku Édouard Glissant, pisarz i myśliciel z Martyniki, prezentując w książce Introduction à une Poétique du Divers (Wprowadze- 
nie do poetyki odmienności) wyniki badań dotyczących przeobrażeń artysty jako czytelnika/obserwatora odmienności kulturowej, zauważa, że koncepcja estetyki odmienności Segalena rodzi pytania związane z problemami globalizacji i metodami jej przeciwdziałaniu, które współcześnie podejmują badania postkolonialne. Pod koniec XX wieku, Segalen, pisarz z początku XX wieku oraz jego rówieśnicy: Blaise Cendrars i Antonin Artaud jawią się jako wpływowi myśliciele antycypujący tę problematykę (Glissant 1990: 39-47). Segalen, jako bezpośredni następca Paula Gauguina i Arthura Rimbauda, należy do grupy pisarzy i artystów, którzy za pomocą „postsymbolistycznej poetyki przemieszczania” dokonywali weryfikacji kolonialnego egzotyzmu z końca XIX wieku. Wkład Segalena w tę poetykę obejmuje liczne i różnorodne dzieła, spośród których większość nie została opublikowana do jego śmierci. Świadczą one o ogromnej różnorodności zainteresowań ich autora, od etnografii do archeologii, od historii do muzykologii i poszukiwań literackich. Prace Segalena dotyczące badań geograficznych, pomimo trudności z genologicznym dookreśleniem, zostały pogrupowane przez redaktorów w kilka cykli: polinezyjski, chiński, orficki, archeologiczny. Cykl polinezyjski obejmuje dzienniki podróży po wyspach Pacyfiku, teksty poświęcone Gauguinowi, szkic powieści, której głównym bohaterem miał być francuski malarz oraz powieść Les Immémoriaux (Niezapamiętany świat). Klasyfikację, uzasadnioną, jak można by sądzić na pierwszy rzut oka, zaburza jednak fakt, że Paul Gauguin jako kluczowa postać prywatnej mitologii Segalena jest obecny we wszystkich napisanych przez niego pracach, będąc jednocześnie głównym bohaterem pierwszego i ostatniego tekstu, który przygotował do druku przedmowy do wydania korespondencji Gauguina z malarzem Danielem de Monfriedem. Gauguin pojawia się w przemyśleniach Segalena na temat egzotyzmu przez całe jego życie, od pierwszego spotkania z dziełami malarza do tekstu Essai sur l'exotisme: Esthetique du Divers (Esej o egzotyzmie: estetyka odmienności), opublikowanego wiele lat po śmierci autora. Jednocześnie w jego pracach biografia Gauguina nabiera wymiaru fikcyjnego i symbolicznego, ulegając w ten sposób mityzacji.

Gauguin jest dla Segalena „człowiekiem poza prawem”. Patrząc na wychudzoną twarz malarza z Autoportretu na Golgocie, tekst Gauguin dans son dernier décor (Gauguin w swoich ostatnich dekoracjach, 1904) Segalen zamyka słowami przyjaciółki Gauguina, Tioke: „Teraz już nie ma ludzi” (Segalen 1904: 685). Segalen jako pierwszy dokonuje w nim ufikcyjnienia życia Gauguina, co następnie uczyni Sommerset Maugham w powieści Moon and Sixpence (Księżyc i miedziak, 1919), a współcześnie MarioVargas Llosa w powieści El Paraíso en la otra esquina (Raj tuż za rogiem). Aż do 1916 roku w rękopisach Segalena odnajdujemy notatki i warianty przygotowywanej powieści Maître-de-Juir (Nauczyciel rozkoszy), ukazującej Gauguina jako proroka z Zachodu, któremu została powierzona misja przywrócenia kulturze tahitańskiej tego, co utraciła, „nagiego radosnego życia”. W jednym z listów do przyjaciela Segalen pisze: „Pewne aspekty życia Gauguina świadczą o tym, że malował on tego człowieka. Należy tylko ponownie wyśnić jego sen” (Segalen 1904). 
Nieukończoną powieść, opublikowaną kilka dziesięcioleci po śmierci pisarza, rozpoczynają słowa: „Nie udało mi się poznać tego człowieka, przynajmniej za życia, nie twierdzę nawet, że kiedykolwiek udało mi się zbliżyć do niego" (Segalen 1995).

Bohater Segalena postrzega obecność przedstawicieli świata Zachodu na Tahiti w kategoriach narastającego zagrożenia, obserwuje zobojętnienie tubylców wobec śmiercionośnej degradacji ich kultury. Nauczyciel rozkoszy pragnie ożywić „martwe głosy" i, aby przeciwstawić się zgubnej estetyce egzotyki Pierre'a Lotiego, proponuje subwersyjną formę artystycznej interwencji, umożliwiającej Tahitańczykom odrzucanie zachodnich wpływów i ponowne odkrywanie tradycji, o której myślano, że wymarła. Jeżeli przyjrzymy się praktykowanemu współcześnie na Tahiti i Markizach łączeniu tradycyjnych badań nad tradycją z problematyką ekologiczną, okazuje się, że poglądy Segalena stanowią antycypację pewnych problemów aktualnych także w XXI wieku...

Segalen postrzega artystyczną interwencję jako zewnętrzną ingerencję, której celem jest ochrona zagrożonej kultury przed wpływami europejskimi i autochtoniczną obojętnością wobec tych wpływów. Współcześnie, podejście Segalena interpretowane jest także jako radykalne odrzucanie modelu hybrydowości biologicznej i kulturowej (Staszak 22; Fléchet 16; Bardin). Jednak dla Segalena Gauguin był egzotyczny w równym stopniu, co mieszkańcy wysp, na których mieszkał francuski malarz.

Segalen w sztuce Gauguina, poprzez egzotykę, odkrywał możliwość uwolnienia się od kontekstu piętna własnego pochodzenia oraz europejskiego i chrześcijańskiego dziedzictwa kulturowego. Właśnie dlatego obraz Bretońska wioska w śniegu (Village breton sous la neige, około 1894 roku) Gauguina odczytywał on podwójnie - z perspektywy swoich doświadczeń i swojego stosunku do rodzimej Bretanii, ale i przez pryzmat „egzotyki” miejsca powstania tego płótna (Segalen był przekonany, że dzieło to powstało na wyspie Hiva Oa, jednak nowsze analizy pozwalające ustalić przybliżony czas powstania dzieła nie pozwalają wykluczyć, że Gauguin namalował je w Bretanii). Natomiast inny obraz przedstawiający Bretanię przysypaną śniegiem, Boże Narodzenie (La nuit de Noël), w katalogach datowany na 1901 lub 1902 rok, pochodzi z czasów pobytu Gauguina na Markizach, co koncepcję Segalena czyni zasadną. $W$ ostatnich latach życia Segalen przygotowywał szkic powieści Les Immémoriaux bretons (Bretoński niezapamiętany świat), w której podróż ku inności miała odbywać się w przeciwstawnym kierunku, w głąb siebie, a każdy jej rozdział poświęcony Tahiti miał zostać odwzorowany jako rozdział o Bretanii (Segalen 1995: 1098-1099).

Proces zmian kulturowych i kontrasty między kulturami wywołują niepokój, międzykulturowa wymiana "spojrzeń" narusza podstawy dążenia do ujednolicania, czy, odnosząc tę problematykę do współczesności, globalizacji. Można porównać tę sytuację z „budowaniem od dołu”, opisanym przez Jovicę Aćina jako postępowanie, w którym „pod danym fundamentem umieszczamy nowy, a pod nim kolejny. 
Pod istniejący fundament podkładamy drugi” (Aćin 68-70). Takie „podbudowywanie nowych podstaw" w sposób nieunikniony zachwieje budowlą posiadającą swój pierwotny fundament. Nie ulega także wątpliwości, że opisany sposób budowy wymaga nieporównywalnie więcej wysiłku niż „,budowanie od góry”, czyli metoda nazywana „nadbudowywaniem”. Wymiana kulturowa elementów radykalnie odmiennych stanowi podstawę koncepcji egzotyzmu Segalena. Mogłaby to być także "historia oddolna" Luciena Febvre'a, który powołując się na Jeana Jaurèsa, chciał, aby historia w ujęciu szkoły Annales była "historią oglądaną od dołu, a nie od góry” (Febvre 576). Egzotyzm jest według Segalena relacją obustronną, relacją wielości wzajemnych spojrzeń: obserwujący powinien być świadomy faktu, że egzotyczny obserwowany odwzajemnia mu równie zdziwione spojrzenie, że obserwator także jest odmienny/egzotyczny dla obserwowanego.

Kultury odznaczające się radykalną odmiennością opierają się spojrzeniu innego, a świadomość nieprzenikalności tego, co inne, odgrywa kluczową rolę w estetyce odmienności. Kultury takie nie są w stanie wzajemnie się dopasować i uzupełniać. Próby podłożenia nowych fundamentów, pod ich własne, grożą katastrofą. Segalen chce zaproponować właśnie to ryzyko, a nie samą katastrofę. Komentując powieść Les Immémoriaux (Niezapamiętany świat), Segalen w 1906 roku pisał do Monfrieda: „Starałem się 'pisać' Tahitańczyków tak, jak malując ich, patrzył Gauguin: wychodząc od nich samych, od wnętrza i kierując się na zewnątrz" (Segalen 2004: 660 i 1995: 361-362, cyt. za Forsdick 63). Pod "gmachem”, który powołując się na Gauguina, „wznosi” Segalen, konieczne było tworzenie „nowych fundamentów” - w ten sposób powstawała powieść Les Immémoriaux. Czy u ich najgłębszych podstaw leżała myśl malarska Gauguina, czy też całkowita odmienność świata Tahitańczyków? Przecież także bretoński pejzaż jest odmienny, ale w innym sensie, poprzez podobieństwo-w-różnicy: zarówno bretońskie, jak i maoryskie wioski zasiedlają różnorodne bóstwa, duchy, diabły. Mity i legendy różnią się, ale zagrożenie zatonięcia w monotonii identyczności jest tożsame. Dlatego właśnie, dzięki Gauguinowi Segalen odkrył („,pisząc ich”) nie tylko Tahitańczyków, ale i Bretończyków.

Niedługo po przybyciu na Tahiti Segalenowi jako lekarzowi marynarki wojennej powierzono zadanie opieki nad ofiarami cyklonu, który przeszedł nad wyspami archipelagu Tuamotu. W czasopiśmie „Armée et Marine” (Wojsko i marynarka wojenna) 17 kwietnia 1903 roku pisarz opublikował sprawozdanie na temat tego nieszczęścia, nie omieszkawszy stwierdzić, że pozostały po nim „,smutne pozostałości hybrydycznego życia dzikusów zdążającego ku ułomnościom cywilizacji” (Segalen 1995: 78-87). Drugie czekające go zadanie dotyczyło spuścizny po Gauguinie. W powieści Journal des îles (Dziennik z wyspy), na którą składają się listy do rodziców, oraz w artykule Gauguin dans son dernier décor (Gauguin w swoich najnowszych dekoracjach), opublikowanym w czerwcu 1904 roku w czasopiśmie "Mercure de France", Segalen nazywa choroby, opium, alkoholizm mianem różnorodnych form bata, jakim jest dla ludności tubylczej kontakt z cywilizowanymi ludźmi. Twierdzi 
też, że każda cywilizacja i religia, będąca jej kwintesencją, jest śmiercionośna dla innych ras (Segalen 1904: 679-685). W tekście Voix mortes: musique maori (Martwe głosy: muzyka maoryska), opublikowanym w październiku 1907 roku w czasopiśmie „Mercure de France”, Segalen zauważa, że zagłada muzyki maoryskiej rozpoczęła się 4 marca 1697 roku, kiedy statek Duff z protestanckimi misjonarzami przycumował u wybrzeży Tahiti. Dzieła dopełniła obecność katolickich misjonarzy, a ostateczny cios zadali kulturze maoryskiej w XIX wieku urzędnicy, żandarmi i nauczyciele. Proces zabijania pamięci cywilizacji polinezyjskiej Segalen przedstawia jako proces przemian języka, ujmując je w kategoriach zmiany znaczeń imion ludzi i bogów oraz zachowań. Piękno wolnej miłości ulega dezintegracji za sprawą "Wstydu”, zaś Gauguinowi przypisane zostaje miano skandalisty. Zanikają objęte baczną kontrolą uroczystości, biesiady i taniec. Cuda i boskie natchnienie, którymi niegdyś się zachwycano, stają się teraz przedmiotem drwin. Definitywny koniec kultury maoryskiej następuje wraz z wprowadzeniem "nowego prawa”, czyli systemu donosicielstwa i kar, przypominającego ten, który Europejczykom jest znany z czasów Inkwizycji (Segalen 1907: 1001-1027).

W powieści Journal des îles (Dziennik z wyspy) zepsucie i rozkład, które dostrzegają czytelnicy, jej bohaterowie postrzegają jako postęp. Segalen staje się świadkiem, który stawia pytanie o to, dlaczego nikt nie zapobiegł temu procesowi? Dlaczego postępował on tak szybko? Czy jest on nieodwracalny? Pisarz zastanawia się nad tym, czy jest to naprawdę upadek pewnej kultury, czy strategia przetrwania? Przecież - stwierdza - Polinezyjczycy, niezwykle podatni na wpływy, delektowali się zachodzącymi w nich przeobrażeniami i zachwycali postępem, co długo pozostawało ukryte przed wzrokiem Europejczyków. Segalen zauważa także, że Tahitańczycy nie tylko wstydzą się „pamiętać”, ale nawet z entuzjazmem, jak mu się wydaje, podejmują wysiłki zmierzające do "stłumienia” pamięci o przeszłości. Obawiają się swojej niegdysiejszej religii, „pożeracza oczu”.

Lecz według Segalena - Europejczyka, chrześcijaństwo, potępiając istotę seksualności, dokonało spustoszenia raju, jakim była Tahiti. Segalen, odnalazłszy drogę, wskazaną przez Gauguina, w szkicach do powieści Maître-de-Juir (Nauczyciel rozkoszy) uczynił z Gauguina bohatera swojego buntu, ukazując go jako artystę stojącego poza prawem oraz wszelkimi ludzkimi czy religijnymi powinnościami, jako artystę odtwarzającego to, czego nie przechowała pamięć, przywołującego to, co w pamięci nieuchwytne, nienamacalne. Gauguin widziany oczyma Segalena jest człowiekiem zdolnym przywrócić światu utracone szczęście, przekazującym pogański geniusz w bolesnym akcie rozkosznej zemsty dokonanej na religii chrześcijańskiej. Wykorzystując etnograficzną dokumentację, którą inkrustuje cytatami z Biblii, Segalen tworzy satyryczną powieść o niezwykłej sile oddziaływania, by posługując się materią literacką, zrealizować to, co w zakresie sztuk plastycznych było zamierzeniem Paula Gauguina. Posługując się hybrydyczną kombinacją satyry i poezji, Segalen od-twarza inny świat, odmienny od tego, który sam się narzuca. 
W 1891 roku Paul Gauguin, mając nadzieję na to, że uda mu się uciec przed zachodnią cywilizacją, osiedla się na Tahiti, początkowo w Papeete, później na Pacca, ale i to wydaje mu się niewystarczające. Przeprowadza się tysiąc pięćset kilometrów dalej, na Markizy. Utrudniający mu poruszanie staw kolanowy, uszkodzony przed laty podczas bójki w bretońskiej wsi i malarskiej kolonii Pont-Aven, jest cielesnym wspomnieniem o Bretanii jako o miejscu spotkania z odmiennością, a nawet $\mathrm{z}$ egzotyką.

We wrześniu 1904 roku Segalen wsiada na okręt Dirans i opuszcza Tahiti. Powrót trwa długo: w październiku, po przybyciu na Jawę, artysta przeżywa ogromne rozczarowanie, którego doznaje z chwilą uświadomienia sobie potęgi oddziaływania kultury Zachodu na tubylców. W listopadzie i grudniu dociera na Cejlon, gdzie spotyka się z buddyjskimi mnichami i odkrywa sanskryt. Będą mu potrzebne jeszcze trzy lata, aby ukończyć powieść Les Immémoriaux (Niezapamiętany świat) i wydać ją w 1907 roku pod pseudonimem Max-Anély. Książka nie zostanie dostrzeżona przez francuską publiczność czytelniczą, zachwycającą się malowniczą egzotyką Lotiego, w której Segalen dostrzega jedynie upodlenie poczucia odmienności (Segalen 2014: 54). Jej katalizatorami są - według Segalena - nieprzystosowanie, wyłączność, pragnienie, sen, wyobraźnia, poświęcenie, zaś tłumi je przyzwyczajenie, bliskość, adaptacja, chęć posiadania, oswajanie, słowem: inwazja homogeniczności. W marcu 1909 roku, w Cherbourgu pisze:

[...] rozpaczliwe poszukiwanie mistycznej czystości poprzez odurzenie Huysmansem oraz odurzającej czystości za pomocą halucynacji. [...] Ci, którzy gest ciała przetworzyli w gest higieny, za sprawą tej zamiany utracili wszystko, otrzymując jedynie zgaszoną homogeniczność, w której umiera poczucie Odmienności (Segalen 2014: 62).

Sądząc na podstawie listów do przyjaciół wysyłanych przez Paula Gauguina przed podróżą na Tahiti (Joly-Segalen 1950), przekonanie o idylli, w której żyją mieszkańcy wysp Pacyfiku, było tak silne, że po przybyciu na nie, doznał on wielkiego rozczarowania. „Nowa Cytera” („Nouvelle Cythère”) Bougainville'a, „wyspa szczęścia" Lotiego okazały się przekłamanymi wizjami. Paul Gauguin, doświadczony żeglarz i podróżnik, później także Victor Segalen, lekarz marynarki wojennej byli świadomi konsekwencji naukowej, handlowej i misyjnej aktywności w rejonie Pacyfiku. W 1880 roku wyspa Tahiti zmieniła swój status z protektoratu w kolonię Francji, stając się bardziej przystępnym terytorium dla artysty, który, ze względu na odległość dzielącą go od kupców, mógł kontynuować swoją działalność jedynie dzięki efektywności francuskiej biurokracji kolonialnej i sprawnej działalności urzędników pocztowych.

W 1897 roku Gauguin, odczuwając coraz większe wyczerpanie, podjął decyzję o stworzeniu wielkiego płótna D'où venons-nous? Que sommes-nous ? Où allons- 
-nous ? (Skąd przybywamy? Kim jesteśmy? Dokąd zmierzamy?): „Przed śmiercią chciałem stworzyć ogromny obraz. [...] Włożę w niego, zanim umrę, całą swą energię, bolesną namiętność tych przerażających okoliczności, wizję, [...] z której wyłania się życie". Był to jego testament, jak napisał w lutym 1898 roku, w liście z Tahiti do swojego przyjaciela, Daniela de Monfrieda, z którym później zaprzyjaźni się Segalen.

Najbardziej ambitne płótno Gauguina nosi tytuł będący zagadkowym pytaniem bez odpowiedzi. Jego możliwe pochodzenie historycy literatury i malarstwa wywodzą od Thomasa Carlyle'a do Charlesa Darwina, natomiast, jak się wydaje, impulsem do jego powstania była potrzeba podjęcia przez Gauguina tematyki ludzkiego istnienia (Gauguin-Tahiti 181-182; Monro 273-276). Ten monumentalny obraz o długości 4,5 m i wysokości 1,7 m Gauguin namalował podczas pobytu na Tahiti. Wówczas także napisał pierwszą wersję rękopisu Noa Noa, w którym poprzez tekst i rysunek po raz pierwszy stawia to właśnie pytanie. Kiedy w 1901 roku przenosi się z Tahiti na Markizy, nie rozstaje się z rękopisem. Powraca do niego w ostatnim roku życia, uzupełniając go i przeredagowując, a ostateczną wersję opatruje tytułem L'Eglise catholique et l'Esprit moderne (Kościół katolicki i duch moderny).

Po ukończeniu prac nad obrazem, Gauguin usiłuje popełnić samobójstwo. Pisze do Monfrieda:

Postanowiłem się zabić. Ukryłem się w górach, gdzie moje ciało zjadłyby mrówki. Nie miałem pistoletu, ale miałem arszenik: nie umiem stwierdzić, czy za sprawą zbyt dużej dawki, ale faktem jest, że wszystko zwróciłem, neutralizując działanie trucizny. Nie wiem. Jednym słowem, po całej nocy okropnych katuszy, wróciłem do domu.

Wyjazd na Markizy stanowił dla Gauguina próbę jeszcze większego zdystansowania się do "cywilizacji”, w celu - jak pisał - wzbogacenia własnego malarstwa „nowymi, przerażającymi elementami”, za sprawą których „Tahiti stanie się zrozumiałe i fascynujące. Moje bretońskie płótna są dzięki Tahiti wodą różaną; dzięki Markizom Tahiti stanie się wodą kolońską" (Joly-Segalen 1950: 177).

Był to jego ostatni przejaw energii. W liście do Charlesa Morice'a z 1901 roku napisał:

Zebrawszy ostatki sił w przyszłym miesiącu płynę na Fatu Hiva na Markizach, wyspę, na której jeszcze częściowo panuje ludożerstwo. Mam nadzieję, że ten pierwiastek totalnej dzikości, ta pełnia samotności, której doznam przed śmiercią, wskrzesi ostatni płomień zachwytu, który odmłodzi moją wyobraźnię i zwieńczy mój talent (Malingue 300). 
Vicktor Segalen odkrył filozofię Nietzschego za pośrednictwem przekładów Anri Albera opublikowanych w czasopiśmie "Mercure de France”. W tym czasie, pod silnym wpływem chrześcijaństwa, udręczone ciało Chrystusa i ciało matki dziewicy eksponowane były jako egzystencjalne wzory męskości i kobiecości. Nietzsche postrzega chrześcijaństwo jako religię, która pogardza instynktami, lekceważy namiętności, deprecjonuje ciało, otwiera drogę ku świętości, czystości w relacjach z siłami natury. Dąży do przywrócenia ciału świętości. Nietzcheańskie inspiracje Segalena wiodą ku poszukiwaniom cielesnego wymiaru myślenia. Taki cel przyświeca również Paulowi Gauguinowi. Zarówno malarz, jak i pisarz na wyspach Pacyfiku poszukują świata nieskalanego chrześcijańskim ideałem ascezy. Uciekają oni z purytańskiej Europy, aby na wyspach polinezyjskich doznać oczyszczenia duszy i ciała.

Segalen przez całe życie cierpiał na neurastenię, jak ją wówczas nazywano. W 1900 roku, czyli w roku śmierci Fryderyka Nietzschego, Segalen będąc lekarzem w Wyższej Szkole Marynarki Wojennej w Bordeaux, zdiagnozował u siebie objawy choroby nerwowej. W listopadzie pogrążył się w ciężkiej depresji. Przestał pracować i popadł w długi. Już w kolejnym roku oddawał się poszukiwaniom „sztucznych rajów”, które umożliwiały mu dalsze życie. Do jego końca pozostał opiumistą. Względy osobiste sprawiły, że poświęcił się pracy pt. L'Observation médicale chez les écrivains naturalistes (Obserwacja medyczna u pisarzy naturalistów), będącej jego rozprawą doktorską.

Dzięki podróży na Tahiti Segalen odkrył życie uwolnione od religii nienawiści do ciała. Dostrzegając spustoszenia, jakie w życiu Polinezyjczyków poczynił misyjny kolonializm, pragnąc ocalić ich kulturę, gromadził relikty mitycznej pamięci tej cywilizacji. W październiku 1915 roku pisarz przebywał w szpitalu z powodu ostrego nieżytu żołądka. Jesienią 1918 roku ponownie popadł w ciężką depresję. W Szpitalu Wojskowym w Breście, a następnie w szpitalu Val-de-Grâce zdiagnozowano u niego "ostrą neurastenię". Próbował leczyć się samodzielnie za pomocą opium. Od końca kwietnia 1919 roku mieszkał w Hotelu Angleterre, w wiosce Huelgoat, w Finisterre. Dwudziestego maja napisał ostatnie listy, których nie wysłał: jeden do żony, drugi do drogiej przyjaciółki. Nazajutrz, według świadectwa znajomej z hotelu, wyruszył na spacer po lesie, zabierając ze sobą kosz z kanapkami. Po południu rozszalała się burza. Do wieczora Segalen nie wrócił do hotelu. W czwartek wezwano z Brestu jego żonę, która nazajutrz, po przybyciu wyruszyła ścieżkami, którymi tydzień wcześniej wędrowali do skały wznoszącej się nad przepaścią. Tam znajdowało się jego ciało. Obok niego spoczywał tom dramatów Szekspira, z oznaczoną za pomocą fotografii żony stroną Hamleta, którą kilka dni wcześniej wspólnie czytali; inne miejsca dramatu poznaczone były listami. Do dzisiejszego dnia okoliczności jego śmierci pozostały zagadką - nie wiadomo, czy zmarł z wyczerpania, czy popełnił samobójstwo: „W każdym z nas istnieje [...] jakaś niedostępna jaskinia, której nie możemy się pozbyć [...], ani udostępnić jej innym" (Segalen 1906: 486; 2014: 78). 
Segalen nie miał wątpliwości, skąd przychodzi i dokąd zmierza. Jego celem nie było dotarcie do żadnej rzekomej źródłowej czystości kultury tahitańskiej, czy też jakiejkolwiek innej kultury, lecz dokonanie wyboru pomiędzy tradycjami, które napotykał i które w swoich dziełach odważnie przetwarzał, tłumacząc je - w poszukiwaniu siebie - na własny język, jednak z pełną świadomością tego, że poszukiwania te zakończą się niepowodzeniem, jeżeli nie będziemy w sobie pielęgnować poczucia Odmienności.

\section{Przekład z jezzyka serbskiego: Sylwia Nowak-Bajcar}

\section{BIBLIOGRAFIA}

Aćin, Jovica. Srodnici. Powieść, rękopis udostępniony przez autora.

Bardin, Jacques. Pierre Loti, Victor Segalen et l'exotisme. Thèse de doctorat. Université de Nice-Sophia Antipolis, 1994.

Berban, III, Matthew. „The Origin of Paul Gauguin's 'Vision After the Sermon: Jacob Wrestling with the Angel' (1888)". Art Bulletin 59 (3) (September 1, 1977). S. 415.

Clifford, James. The Predicament of Culture: Twentieth-Century Ethnography, Literature and Art. Cambridge, MA: Harvard UP, 1988.

Diderot, Denis. Supplément au Voyage de Bougainville. Éd. Michel Delon. Paris: Gallimard, Folio classique, 2002.

Febvre, Lucien. „Albert Mathiez: un tempérament, une éducation”. Annales d'histoire économique et sociale 18, 1932. S. 576.

Fléchet, Anaïs. „L'exotisme comme objet d'histoire”. Hypothèses 11 (1/2008). S. 15-26.

Forsdick, Charles. „Gauguin and Segalen: Exoticism, Myth and the 'Aesthetics of Diversity”. Gauguin: Maker of Myth. London: Tate Publishing, 2010. S. 56-63.

Gille, Vincent. „The Last Orientalist: Portrait $\mathrm{f}$ the Artist as Mohican”. Gauguin: Maker of Myth. London: Tate Publishing, 2010. S. 48-55.

Glissant, Édouard. Introduction à une Poétique du Divers. Paris: Gallimard, 1996.

Glissant, Édouard. Poétique de la Relation. Paris: Gallimard, 2014 (1990).

Gauguin-Tahiti, l'atelier des Tropiques. Paris, Galeries nationales du Grand Palais, 30 sept. 2003-19 janv. 2004; Boston, Museum of Fine Arts 29 févr.-20 juin 2004. Commissaires: Claire Frèches-Thory, George T.M. Shackelford, Françoise Heilbrun. Paris: Réunion des musées nationaux, 2003. S. 383.

Hanotaux Gabriel, Martineau Alfred. Histoire des Colonies françaises et de l'expansion de la France dans le monde. Tome VI. Océan Indien - Pacifique - Afrique du Sud. Édit. Librairie Plon. Paris, 1933.

Huyghe, René. „Gauguin, initiateur des temps nouveaux”. Gauguin. Paris: Hachette, col. "Génies et réalités ", 1960.

Joly-Segalen Annie, Loize Jean. De Tahiti au Thibet. Exposition littéraire Victor Segalen (1878-1919). Paris, 1944. 
Joly-Segalen, Annie (éd.). Lettres de Gauguin à Daniel de Monfreid. Précédées d'un hommage à Gauguin par Victor Segalen. Paris: Georges Falaize, 1950.

Leys, Simon. „L'exotisme de Segalen”. Essais sur la Chine. L'humeur, l'honneur, l'horreur. Paris: Robert Laffont, 1998. S. 757-767.

Lotman, Yuri M. „O semiosfere”. Sign Systems Studies (Trudy po znakovym sistemam) 17 (1984). S. 5-23.

Malingue, Maurice (éd.). Paul Gauguin. Lettres à sa femme et à ses amis. Paris: Bernard Grasset, 2003 (1946).

Monro, Jane. Endless Forms: Charles Darwin, Natural Science and the Visual Arts. Eds Diana Donald and Jane Munro. New Haven: Yale University Press, 2009.

Rigo, Bernard. Alterité polynésienne ou les métamorphoses de l'espace-temps. Paris: CNRS Éditions, 2004.

Rigo, Bernard. Lieux-Dits d'un malentendu culturel. Analyse anthropologique et philosophique du discours occidental sur l'altérité polynésienne. Tahiti: Au Vent des îles, 1997.

Segalen, Victor. „Gauguin dans son dernier décor”. Le Mercure de France 174 (1904 juin). S. 679-685.

Segalen, Victor, Essai sur l'exotisme: une esthétique du divers, Paris: Fata Morgan/Le Livre de Poche, coll. «Biblio: essais», 2014 (1978/1986).

Segalen, Victor. „Le double Rimbaud”. Le Mercure de France 212 (1906 avril). S. 481-501.

Segalen, Victor. Les Immémoriaux. Paris: Le Livre de Poche, coll. «Classique», 2014a (LGF 2001).

Segalen, Victor. L'Observation médicale chez les écrivains naturalistes (thèse de médecine). Bordeaux: Y. Cadoret, coll. « Les Cliniciens ès Lettres », 1902.

Segalen, Victor. „Les Synesthésies et l'école symbolistę”. Mercure de France 42, (1902). S. 57-90.

Segalen. Victor. Oeuvres completes. Vol. 1, 2. Éd. Henry Boullier, Paris: Robert Laffont, 1995.

Segalen. Victor. Correspondence I, 1893-1912. Éd. Henry Boullier, Paris: Bernard Grasset, 2004.

Segalen, Victor. „Voix mortes: musique maori”. Le Mercure de France 10 (1907 octobre). S. 1001-1027.

Segalen, Victor. Voyages au pays du réel. Édition présentée et annotée par Michel le Bris. Paris: Éditions Complexe, 1995.

Segalen, Victor. Victor Segalen: voyageur et visionnaire. Exposition, galerie Mansart, Paris, du 5 octobre au 31 décembre 1999. Organisée par la Bibliothèque nationale de France. Sous la dir. de Mauricette Berne. Bibliothèque nationale de France, 1999.

Staszak, Jean-François. „Qu'est-ce que l'exotisme ?". Le Globe. Revue genevoise de géographie 148 (1/2008). S. 7-30.

Thomson, Belinda (ed.). „Paul Gauguin: Navigating the Myth”. Gauguin: Maker of Myth. London: Tate Publishing, 2010. S. 10-23.

Todorov, Tzvetan. Nous et les Autres. La réflexion française sur la diversité humaine. Paris: Seuil, col. «Sciences humaines», 1992.

Voltaire. Correspondance. Établie par Théodore Besterman. Paris: Gallimard, col. «La Pléiade», 1987. Vol. XI. S. 702-703, list nr 13.770. 